\title{
EFFECT OF NITROGEN APPLICATIONS ON THE YIELDS AND COMPOSITION OF FORAGE CROPS
}

\author{
JUAN PASTOR RODRIGGUEZ
}

\section{INTRODUCTION}

The livestock industry is the second most important agricultural enterprise of Puerto Rico. Milk is a most important item in the diet of the Puerto Rican families, especially, for the feeding of children, but we are not producing enough milk so that the population can have an ample supply of this important item.

There are many factors which might increase the production of milk in Puerto Rico, and among them is the improvement of the production and quality of green forage. This is the most important item in the daily ration of the dairy cow. Most of the grasses used in the feeding of livestock in the Island are relatively low in protein content, thus large amounts of imported concentrates, high in protein, must be used by the dairy industry to maintain the milk production at an adequate level.

The chemical composition of the foliage of any crop, however, is not constant, but varies with the climate, the capacity of the soil to provide the crop with the nutrients it needs in sufficient amounts, the age of the plant and other factors. In turn, the capacity of a soil to provide a crop with sufficient amount of the nutrients it requires may be altered by making fertilizer and soil amendments to the soil. The determination of the proper time of applying nitrogen to soils, deficient in this element, would undoubtedly be of help in the improvement of yield per acre and quality of the forage crops, thus increasing the efficiency of the dairy industry.

Several experiments leading to this end were recently conducted at Rio Piedras. The procedures employed and results obtained are described in this article.

The work reported here has been carried out in our main Station farm at Río Piedras, over the period from 1945 to 1948, with the three most important forage grasses, namely, Guinea, Merker and Para-Carib.

Guinea, Panicum maximum Jacq., is principally a pasture grass on both the North and South coasts, but occasionally it is cut and fed green. It is native of Africa, and according to E. D. Colón (4) its introduction dates from the early part of the XVI century. It is said that the seed of this grass was first introduced to Puerto Rico in the straw used for bedding of human cargoes of slave ships from Africa. Hitchcock (7) describes it as follows: "Perennial; culm cespitose, erect, 1 to $2.5 \mathrm{~m}$ tall, glabrous; the nodes densely hirsute; blades flat, elongate, 1 to $3.5 \mathrm{~cm}$. wide, glabrous, 
except the margin, or hirsute on the upper surface near the base: panicle open, 20 to $50 \mathrm{~cm}$. long; the lower branches in whorls; spikelets oblong, glabrous, about $3 \mathrm{~mm}$. long; first glume one-third as long as spikelets; fruit transversely rugose. Found in the open ground, at low altitudes, escaped from cultivation, southern Florida, through Mexico and the West Indies to South America. To be found on all the islands of the West Indies."

Merker, Pennisetum purpureum var. Merkerii Schumaker, has come into favor for green forage in the dairy farms of Puerto Rico. This is really a fine stemmed strain of Napier grass of which a selected variant was introduced to Puerto Rico by this Agricultural Experiment Station, from McNeill Branch Experiment Station, McNeill, Mississippi, in the year 1934. Only a few seed pieces were received for a start, but the propagation was easy and it is now on nearly every farm in the Island. Besides being practically immune to the Helminthosporium leaf spot, it is a high yielder and has high nutritive value. The environmental requirements for its best development are more or less the same as for Napier grass. Both Merker and Napier require a rich soil for best growth. Under favorable conditions they produce enormous amounts of green forage and can be cut several times during the year.

Para-Carib-These two grasses grow in association in Puerto Rico, and in the vicinity of Río Piedras, where this work was conducted, they are inseparably mixed. Very few dairymen or farmers speak of Carib grass, they always talk of the Para grass being the most important grass for the dairy cows. But since these two grasses have been found so mixed in ordinary culture and as it was thought to be rather impracticable to separate them for ordinary planting, it was decided to call Para-Carib the grass mixture in our experimental plots, rather than Para or Carib alone. They certainly differ from one another in some respects. Para grass or "malojillo", Panicum purpurascens Raddi, (7) is a straggling perennial forming a tangled mass along the banks of streams or ditches. It is similar to Carib grass in general appearance but may be distinguished from the latter by the thicker more hairy stems (Alberts and García Molinari) (1), and its larger leaves that are light-green in color. Para or "malojillo", blooms from October to December, while Carib grass blooms throughout the year. During the non-blooming period, Para grass can be distinguished in the field from Carib grass by its hairy non-flowering stem that projects several inches above the stems of the Carib grass.

The Carib grass, "malojilla", Eriochloa polystachya H.B.K., resembles Para grass (Hitchcock), but differs in the spikelet characters. This grass grows in the same habitat as does Para grass and they are frequently found growing in association. It appears to have the same forage value as Para grass. In the continental United States the name used is Carib grass. 


\section{REVIEW OF LITERATURE}

The work presented here deals with the influence of nitrogen treatments on the yield and composition of forage grasses. No attempt has been made, therefore, to cover the literature along the line of forage production and management.

Pasture and forage grasses, almost everywhere, seem to be rather low in protein content, therefore, increasing attention has been given to the improvement of their yield and composition.

Brown (2), at the Storrs Experiment Station in Connecticut, in summing up his five-year work on the effect of various fertilizer treatments on the seasonal production of permanent pastures, states that: "Although the total production has been increased by fertilization, none of the treatments has affected very markedly the proportion of the total feed produced in a given part of the season. During the 5 years of $1927-31$, the mineral plus nitrogen plots produced 252 feed units $(17 \%)$ per acre per year more than the plots receiving mineral only. Of this difference in favor of nitrogen, over two-thirds was produced during the zenith period, May 15, June 15, and the remainder before May 15. Applying one-half of the nitrogen in July, rather than all in April, has resulted in slightly less total feed, but in about $8 \%$ more grazing during the late summer months."

Brown and Munsell (3) in Connecticut, in comparing the yield and quality of several grasses fertilized with nitrogen for hay and pasture with legume and legume-grass mixture report a high increase in total yield as stimulated by nitrogen over the mineral fertilization. In this respect the authors state: "On grazed permanent pastures, spring-applied nitrogen stimulated a $30 \%$ increase in total yield over mineral fertilization. Most of the addition growth occurred before June 16. Spring and summer nitrogen resulted in less May, but more summer feed than from applying all the nitrogen in April. The most uniform seasonal distribution of pasturage was obtained by adding nitrogen only in the summer, but the returns per unit of nitrogen were about half those from the spring treatment."

Macfarland (8) in England, in his work on time of application of nitrogen as a factor influencing the yield of herbage on permanent pastures, found an immediate and significant increase in yield. He reported that the rainfall affected considerably the yields obtained. But, as regards nitrogen, he found that the percentage recovery of nitrogen was high, varying from 54 to 83 per cent.

Woodman, Evans, and Oosthuizen (12) at Cambridge, England, working on the influence on yield and composition of a single heavy dressing of sulphate of ammonia as compared with that of a small dressing throughout the season, showed that one heavy application will give as high a yield as a 
similar amount of sulphate of ammonia applied in small amounts during the same season.

Dodd (6) in Ohio, experimenting with nitrogen fertilizer on Kentucky blue grass pasture, found that grass treated with nitrogen fertilizer becomes more palatable to the extent that the cattle grazed it more closely than grasses in adjoining areas which had no nitrogen. The time of application in Dodd's work showed results as follows: "Larly spring application of nitrogen fertilizer increased the production in the early spring and also throughout the season. Making a second or third application of nitrogen later in the season materially increased the fall growth. The exact time of response in extra growth resulting from nitrogen treatments appeared to be dependent upon the moisture and temperature conditions."

It was found by Munsell and Brown (10) in Connecticut, that when single applications of nitrogen are made in April they produce its greatest effect in May, after which the nitrogen content fell rapidly and remained low for the rest of the season, but, that when the fertilizer was withheld until June or August, the highest point in total nitrogen for the season was attained in the succeeding cuttings. The application of 56 pounds of nitrogen was required to reach this high point.

As to amount and frequency of applications, Munsell and Brown (10), found that 14 pounds of the nitrogen fertilizer applied six times during the season, produced practically the same increase in average nitrogen content over no treatment as three applications of 28 pounds, and that the fluctuations were less when the applications were made six times per season. A further increase was obtained when 56 pounds of nitrogen were applied three times (116 pounds per season) to Kentucky bluegrass $(0.39 \%)$ and to Rhode Island grass $(0.32 \%)$.

As regard the influence of intensive fertilizing on the yield and composition of good permanent pasture, Woodman and Underwood (12) in England, found the main part of the improvement during the early period of the season. They concluded that the soil of good permanent pasture is capable of supplying assimilable nitrogen at a sufficiently rapid rate to meet the demands for proteins synthesis in the herbage plants, and that only when plants are growing very rapidly, as they do early in the season, are they unable to secure the supplies of nitrogen at a rate consistent with their maximum ability for building up the new protein. At this stage, therefore, the addition of readily available nitrogen to the soil is reflected in a stimulation of the rate of growth. They also found that dressings of sulphate of ammonia caused a slight improvement in the crude protein content of the herbage during the first year of application, the effect being most marked in April and October, but that during the second season of the experiment, however, this improvement was not manifested. Woodman, Evans and 
Oosthuizen (13) in England, who carried out work on the influence on yield and composition of a single dressing of sulphate of ammonia compared with that of periodic small dressings throughout the season, point out that favorable weather conditions should prevail at the time of application for an efficient utilization of the nitrogen fertilizer. They found very pronounced stimulation of early growth and unusually high crude protein content by applying a heavy dressing of sulphate of ammonia to grassland in February under suitable weather conditions. They emphasize that for efficient utilization of an early and heavy application of the sulphate of ammonia the weather conditions at this period of the year must be especially favorable. It has the advantage of encouraging early growth without risk of "scorching" the grasses, and then the additional light dressings, when applied at intervals during the summer months, are effective in the stimulation of growth when the grass normally tends to be scarce. A single heavy application made in the month of February does not extend to these later stages of the summer season.

Colwell and Tisdale (5) in "A summary of the most recent works on nitrogen fertilization" note that: "Studies involving the time of application of nitrogen have not been confined to the United States. Numerous foreign investigators have shown that applying nitrogen in several amendments, instead of in one application, has led not only to increased yields but to increased quality of grain and forage. This increase in quality is reflected in larger amounts of protein. Ranking has likewise shown that the time of application of nitrogen has a marked effect on the yield and quality of wheat under North Carolina conditions. He was also able to show that if lack of growth was caused by insufficient nitrogen applied before April, this effect was manifested throughout the remainder of the season in yield and nitrogen content of the plants."

The foregoing facts indicate that the time and method of placement of nitrogen in relation to soil type and environment are important factors in the proper nutrition of plants.

\section{EXPERIMENTAL METHODS}

The experimental field was located in the main Station farm at Rio Piedras, Puerto Rico. The soil was a Vega Baja Silty Clay of medium fertility which had been planted to sugar cane seedlings for several years.

Roberts (11) has described this type of soil as follows: "Vega Baja Silty clay."-Vega Baja silty clay is the most extensive soil of the Vega Baja series. It occurs in a number of widely separated parts of the humid section, where it occupies bordering or intergrade areas between the alluvial soils and the coastal-plain soils. It lies above normal overflow, but during exceptionally high water it is flooded. The surface soil to a depth of 8 or 10 inches 
is friable light brown or grayish-brown granular acid silty clay loam. This layer changes abruptly to a plastic medium-compact mottled yellowishbrown, gray, and red silty clay or clay subsoil, which continued to considerable depth and becomes slightly more definitely mottled and more acid with depth. Vega Baja silty clay has slightly better natural drainage than Vega Baja clay. It is not so productive as the clay, however, because the soil is more compact and the plant roots can not penetrate it so readily for a supply of plant nutrients and moisture as they can the wet subsoil of Vega Baja clay. Areas associated with the Estación soils have deeper and browner surface soils than typical areas. In some places the mottled subsoil lacks the real color. The texture of the surface soil also varies from place to place, ranging from silty loam to silty clay predominating."

The field was divided into three experimental lots, one for each of the three grasses used in this work. Each lot was then sub-divided into 40 one-hundredth acre plots, each plot 20 feet by 21.78 feet, containing ten rows, 20 feet long. The layout of the experimental field was a randomized block. With five treatments, replicated eight times.

In the first part of this work the nitrogen applications were made as described below. Sulphate of ammonia was used as the only source of nitrogen.

Treatment Rate of Nitrogen Application

A No nitrogen

B $\quad 50$ pounds $\mathrm{NH}_{3}$ per acre

C $\quad 50$ pounds $\mathrm{NH}_{3}$ per acre

D $\quad 50$ pounds $\mathrm{NH}_{3}$ per acre

E $\quad 50$ pounds $\mathrm{NH}_{3}$ per acre
Time of Applications

Immediately after planting or harvesting.

Three weeks after planting or harvesting.

Six weeks after planting or harvesting. Nine weeks after planting or harvesting.

Nitrogen applications were made, in the form described above, to the three grasses: namely, Guinea grass, Merker grass and Para-Carib grass. The grasses were cut and allowed to ratoon four times at intervals of 12 weeks. Two 500-gram samples of each green grass were taken at each harvest and immediately sent to the laboratory for determination of nitrogen and dry matter.

In the second part of this work the procedure was altered and the nitrogen applications were made as follows:

Treatment A. No nitrogen applied (Control).

Treatment B. Nitrogen applied at the rate of 200 pounds Sulphate of Ammonia (equivalent to 50 pounds nitrogen per acre).

1. Immediately after harvesting for Merker.

2. Three weeks after harvesting for Guinea.

3. Six weeks after harvesting for Para-Carib. 
Treatments C, D and E. One-half of the amount of nitrogen applied under treatment B on the same day of application as for B, followed by a similar application nine weeks after harvesting.

Treatment C. Harvested one week after the second application of nitrogen.

Treatment D. Harvested two weeks after the second application of nitrogen.

Treatment E. Harvested three weeks after the second application of nitrogen.

As in the first part of the work, grass samples (500 grams) were taken for the determination of nitrogen and dry matter. The grass samples were weighed in the field of harvest and immediately placed in bags and sent to the laboratory.

The experimental data were carefully recorded and the statistical analyses were made soon after each harvest.

\section{EXPERIMENTAL DATA}

The data obtained clearly indicate that nitrogen applications greatly increase the yield and protein content of our most important forage grasses (Tables 1, 4, 5, 6, 7, 9, 11 and 13): Guinea Panicum maximum Jacq.; Merker Pennisetum purpureum Schumaker, var. Merkerii, and the mixture of Para Panicum purpurascens Raddi., and Carib Eriochloa polystachia H.B.K. The yield of green forage and protein of the grasses which received nitrogen were always more than double the yield of the control plots. It was also demonstrated that the time of application of the nitrogen (in the form of $\left.\left(\mathrm{NH}_{4}\right)_{2} \mathrm{SO}_{4}\right)$ had an influence on both yield and composition of the grasses, (tables 3 and 4 ) but that the best time of application for yield was not the best time of application for maximum protein content.

Accordingly, the procedure of the experiments was altered, thus in this second part of the work results were somewhat different. Both Guinea and Merker grasses showed that applying all the fertilizer (200 pounds sulphate of ammonia per acre) at one time resulted in a maximum production of dry forage and protein, but different results (tables 8, 9, 10, 11, 12 and 13) were obtained with the Para-Carib grass, which gave maximum yields when splitting the amount of nitrogen used, and applying half of it six weeks after cutting, and the remainder, nine weeks later. But, as regards mean nitrogen contents of the grasses in per cent dry matter, all three grasses (Guinea, Merker and Para-Carib) had a higher nitrogen content when they received the fertilizer nitrogen split in two applications and the grasses were cut at ten weeks intervals, and a lower nitrogen content when they received all the nitrogen at one time and the grasses were cut at 12 weeks intervals (tables 14, 15 and 16). It seems that when nitrogen is ap- 


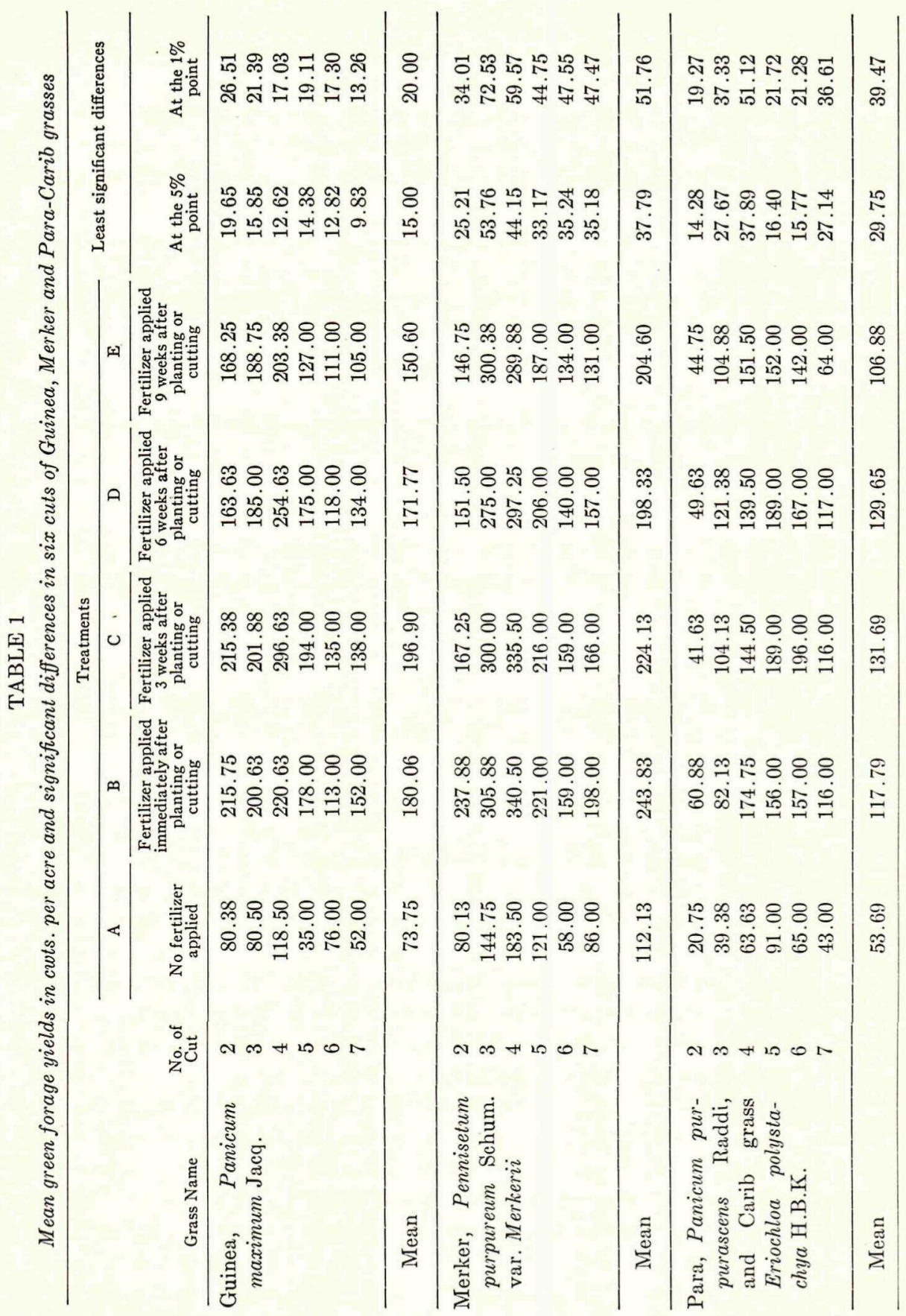




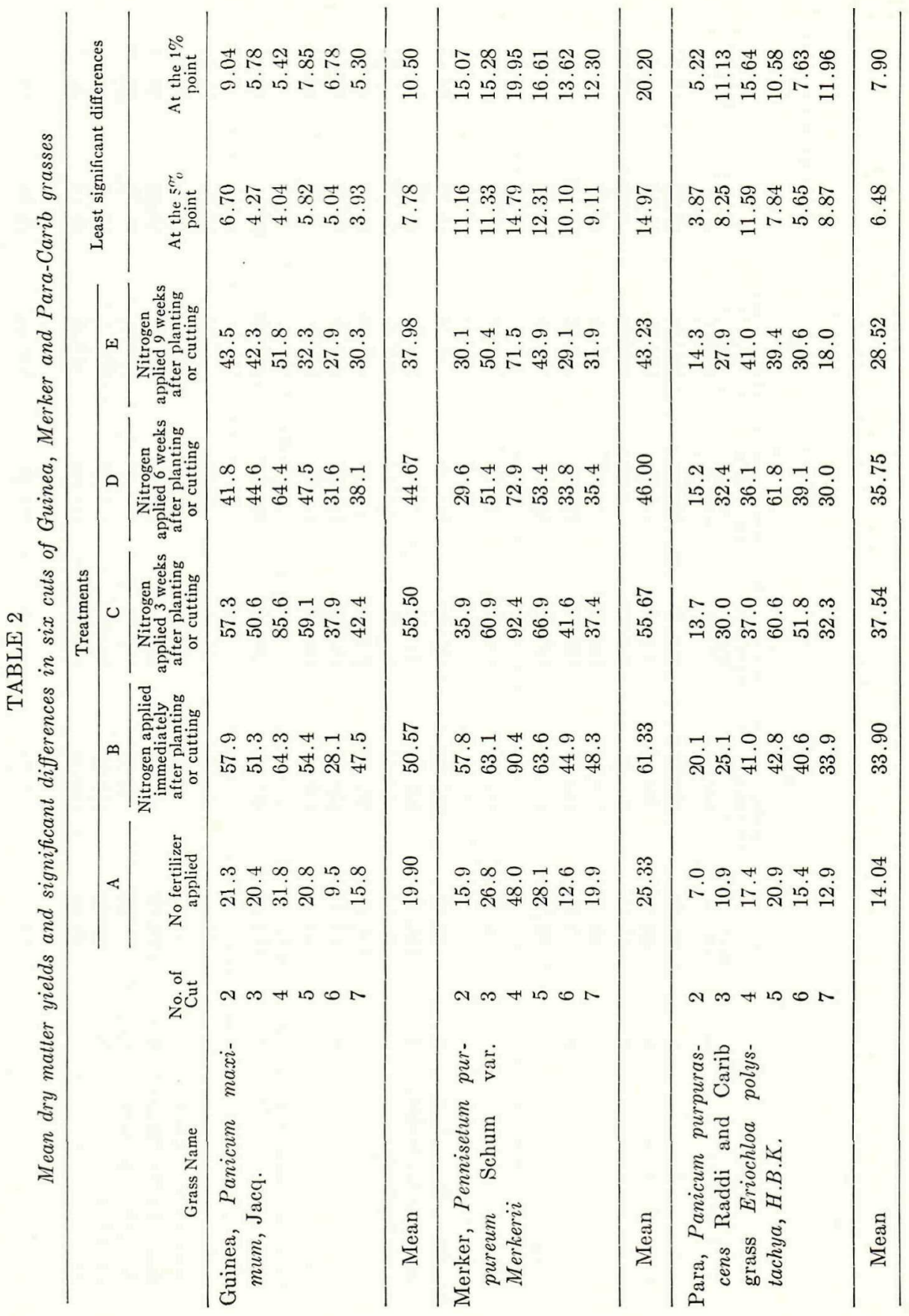




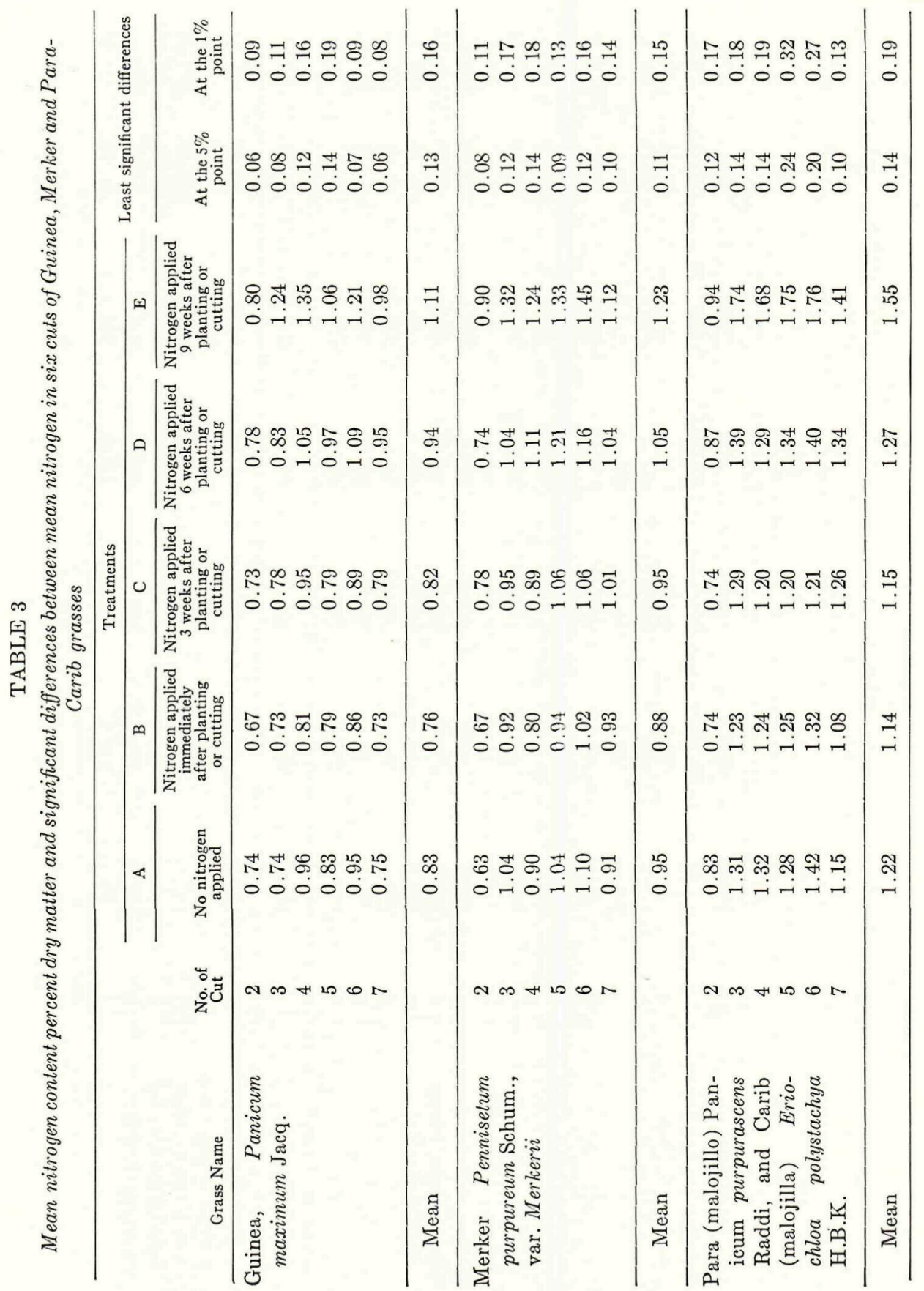




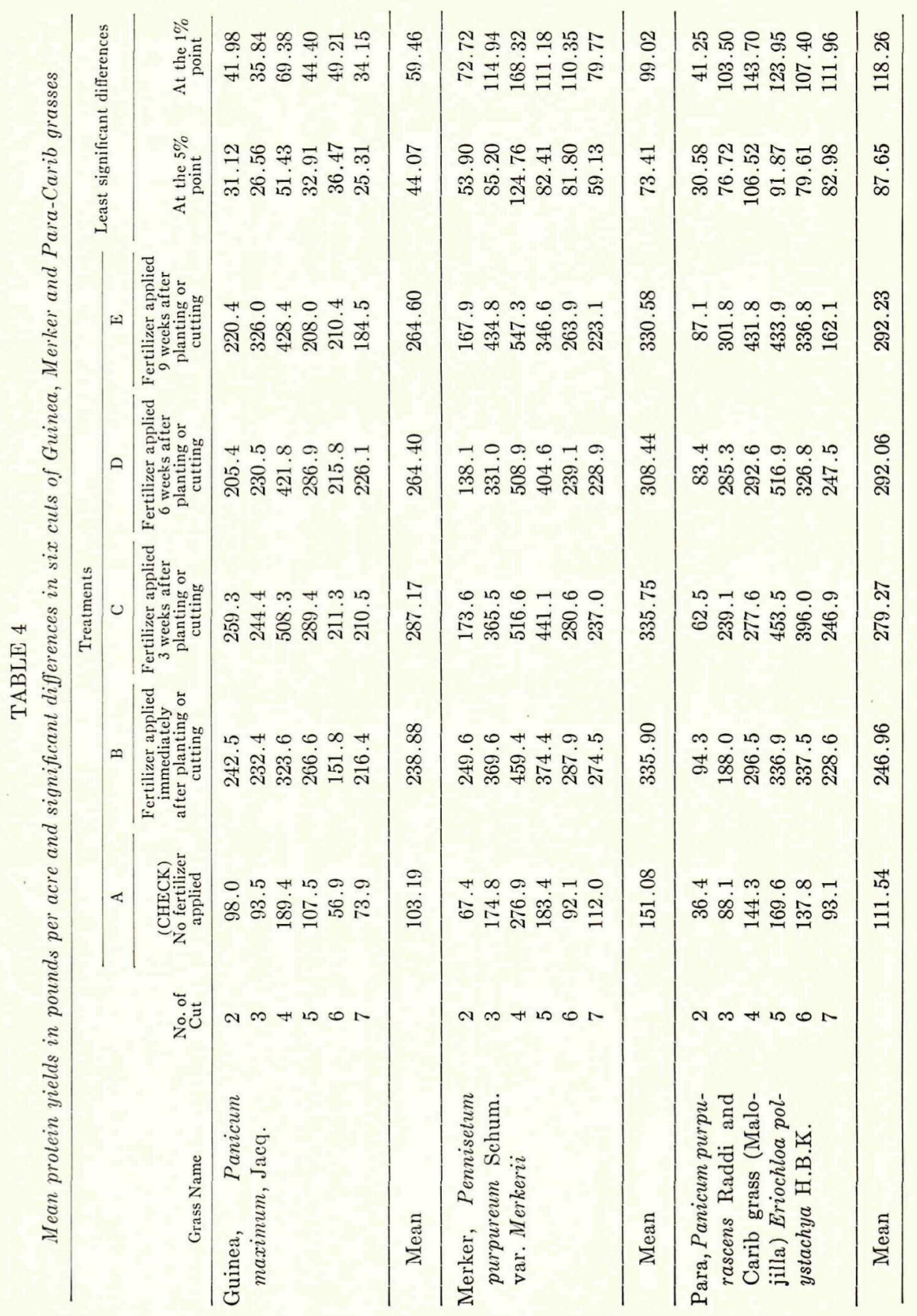




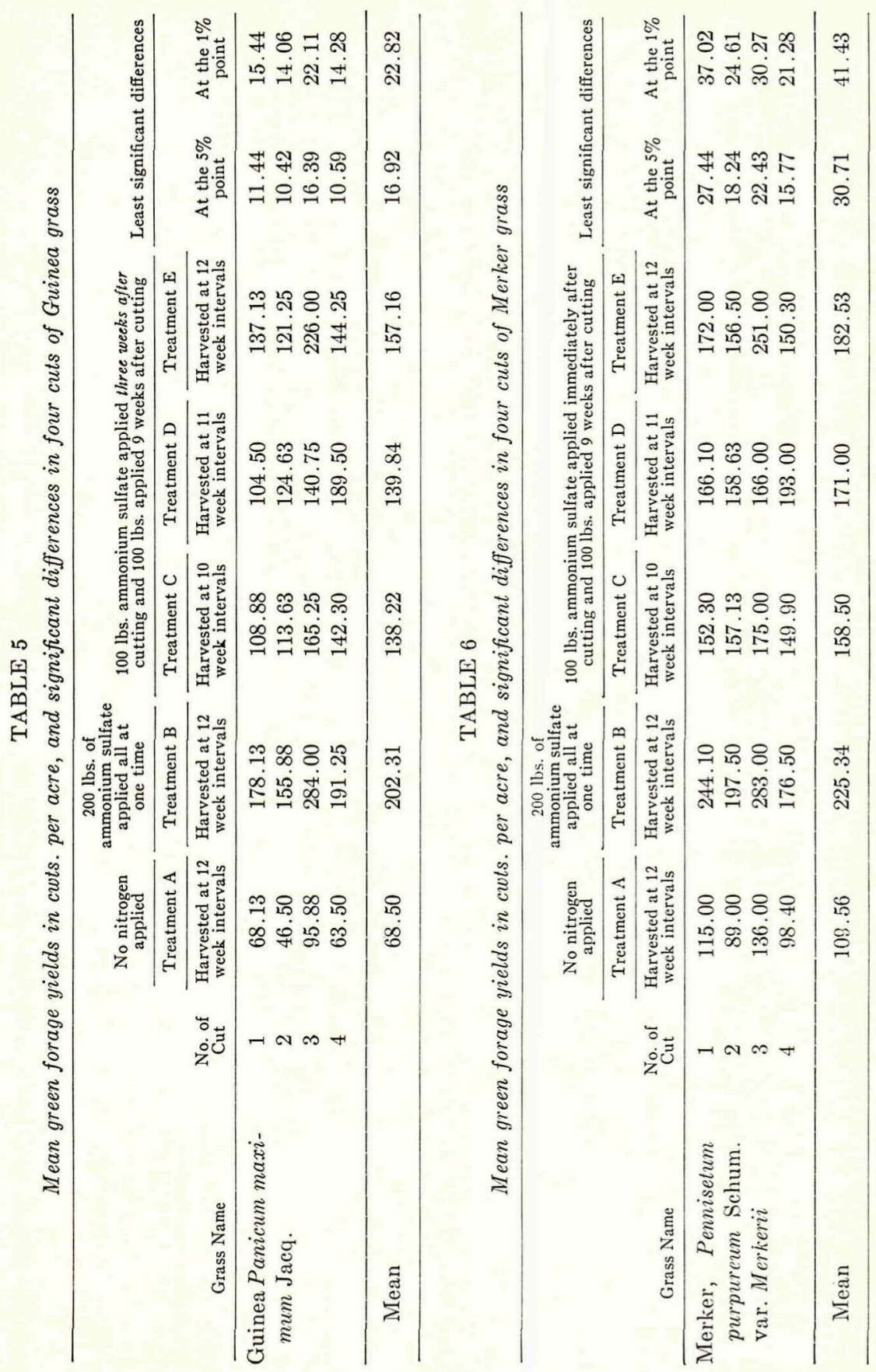



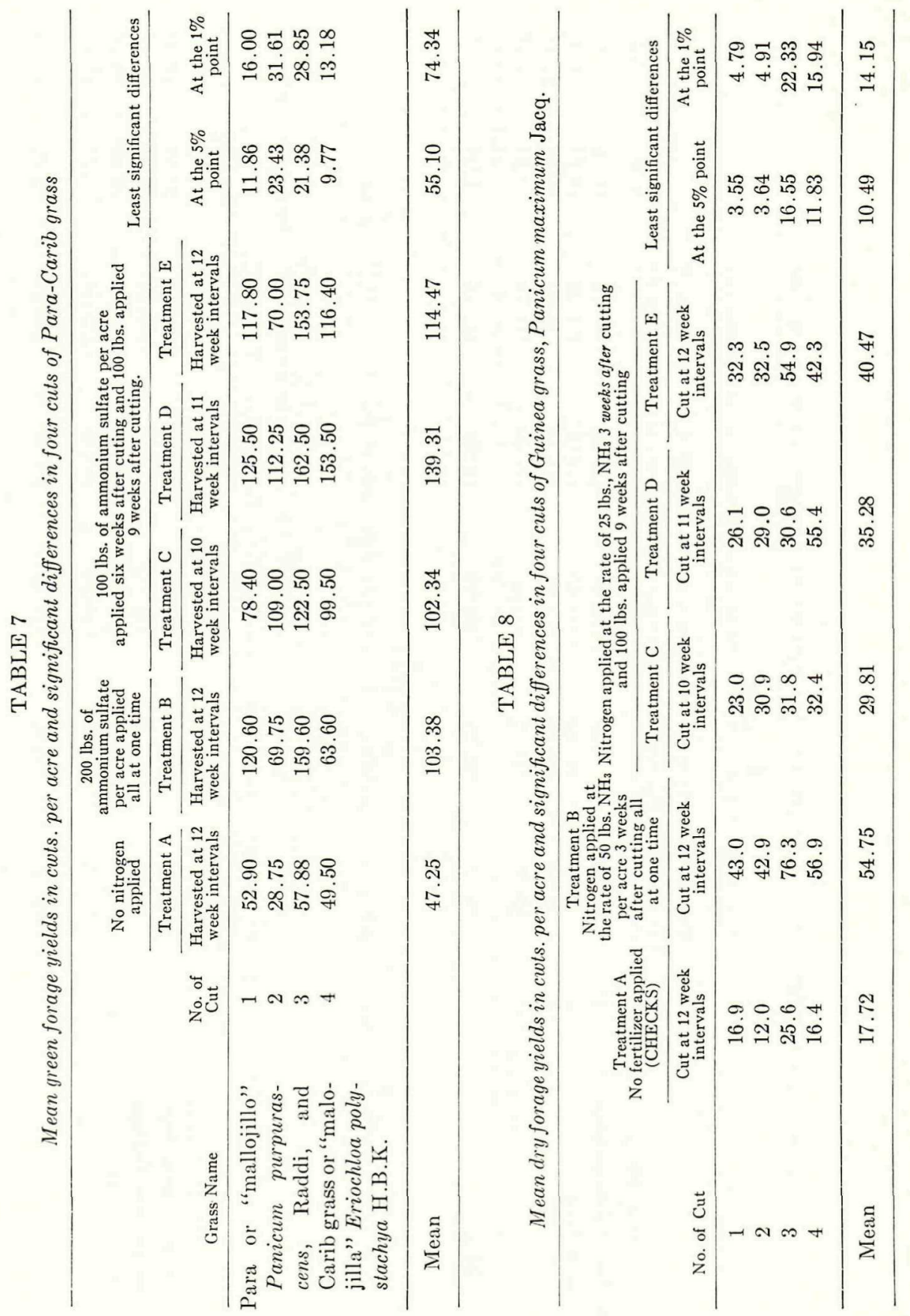

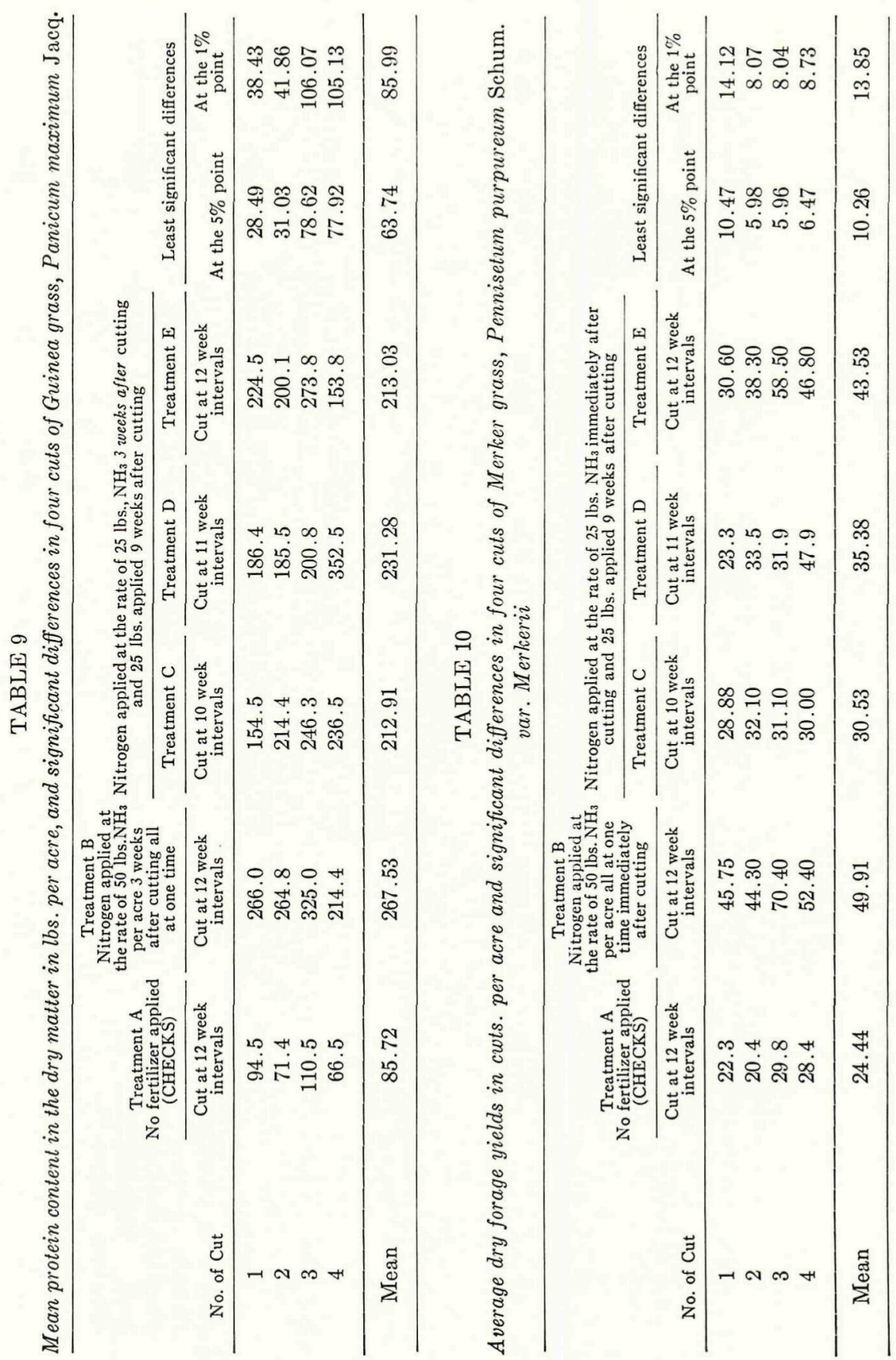


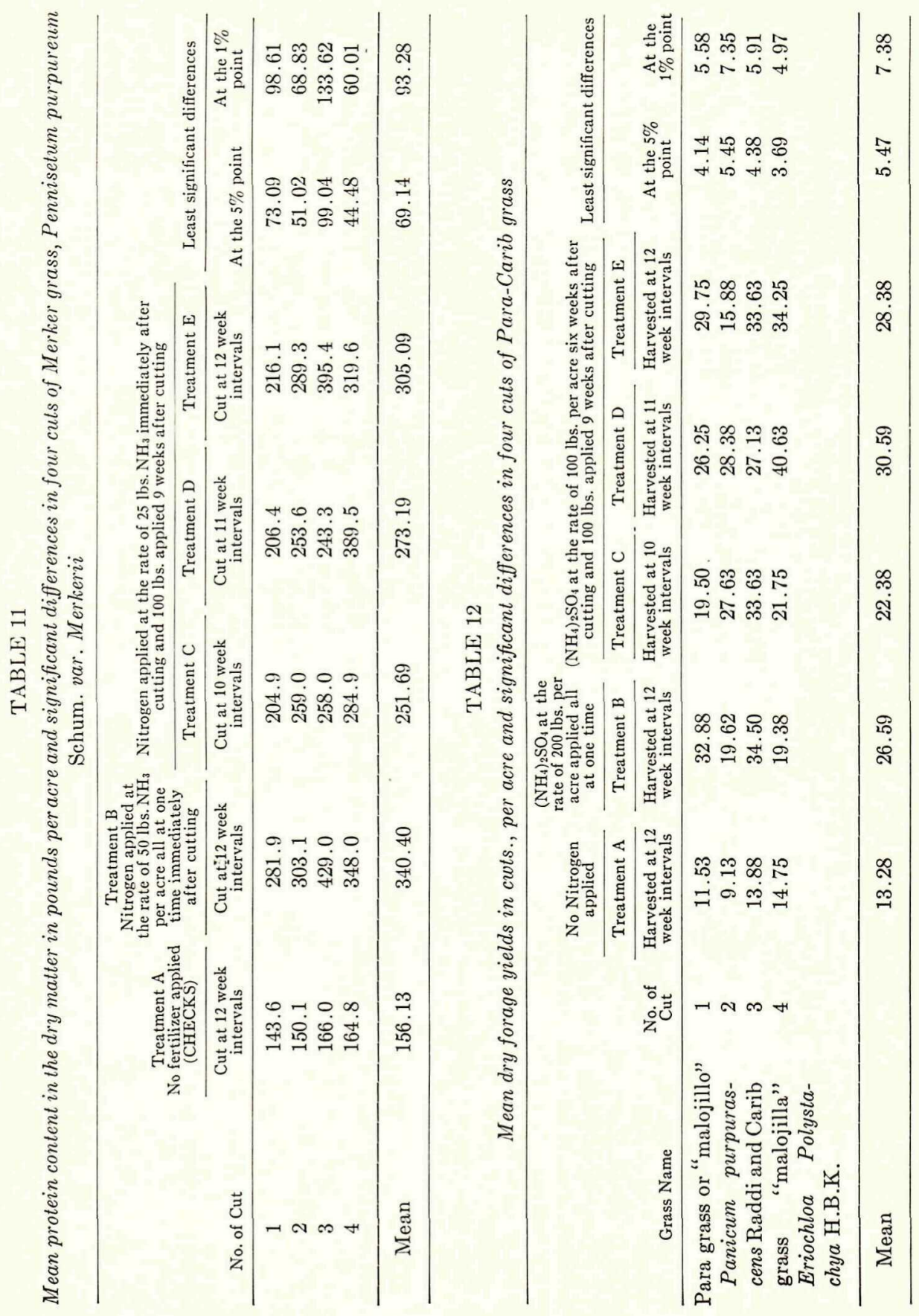



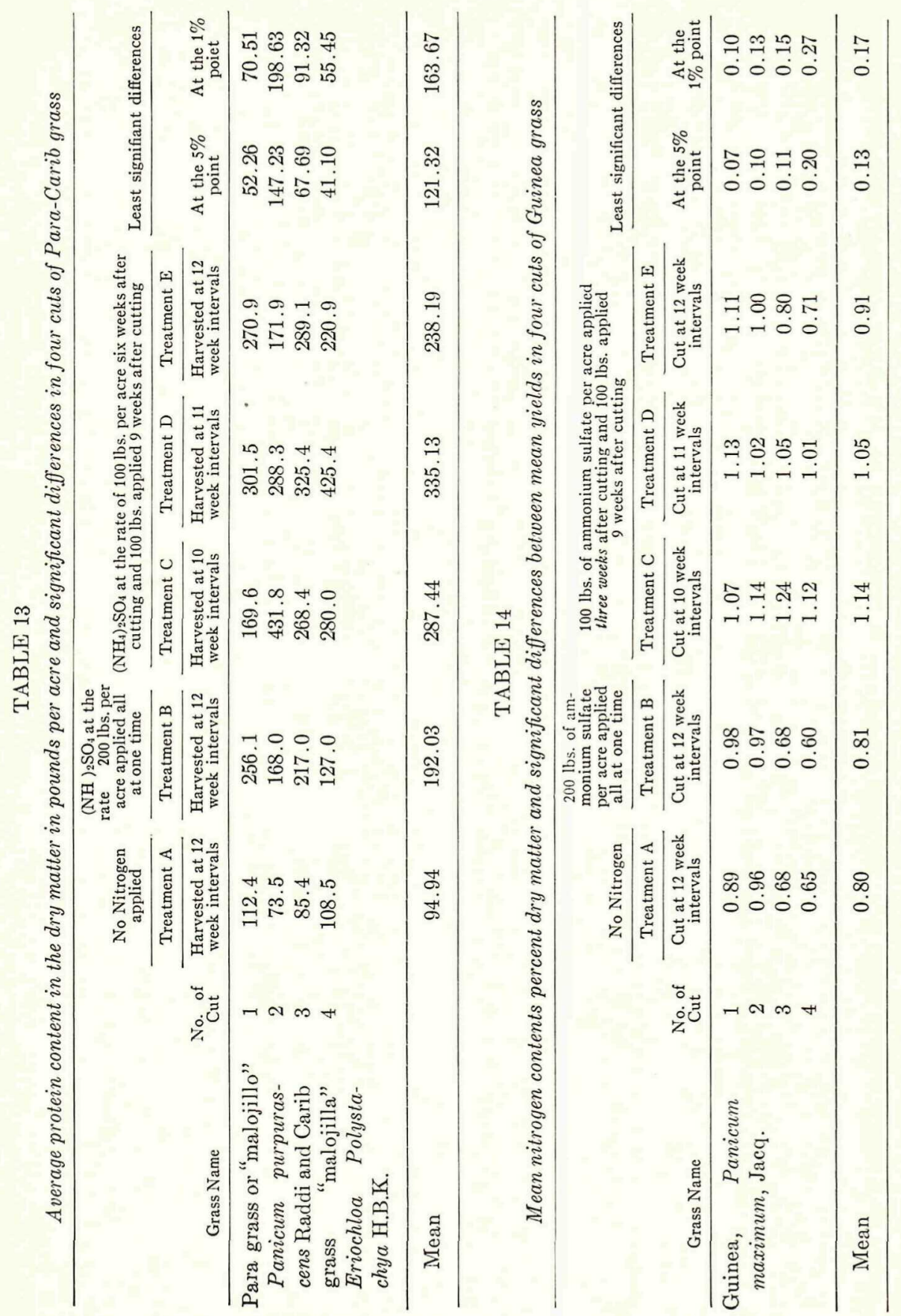


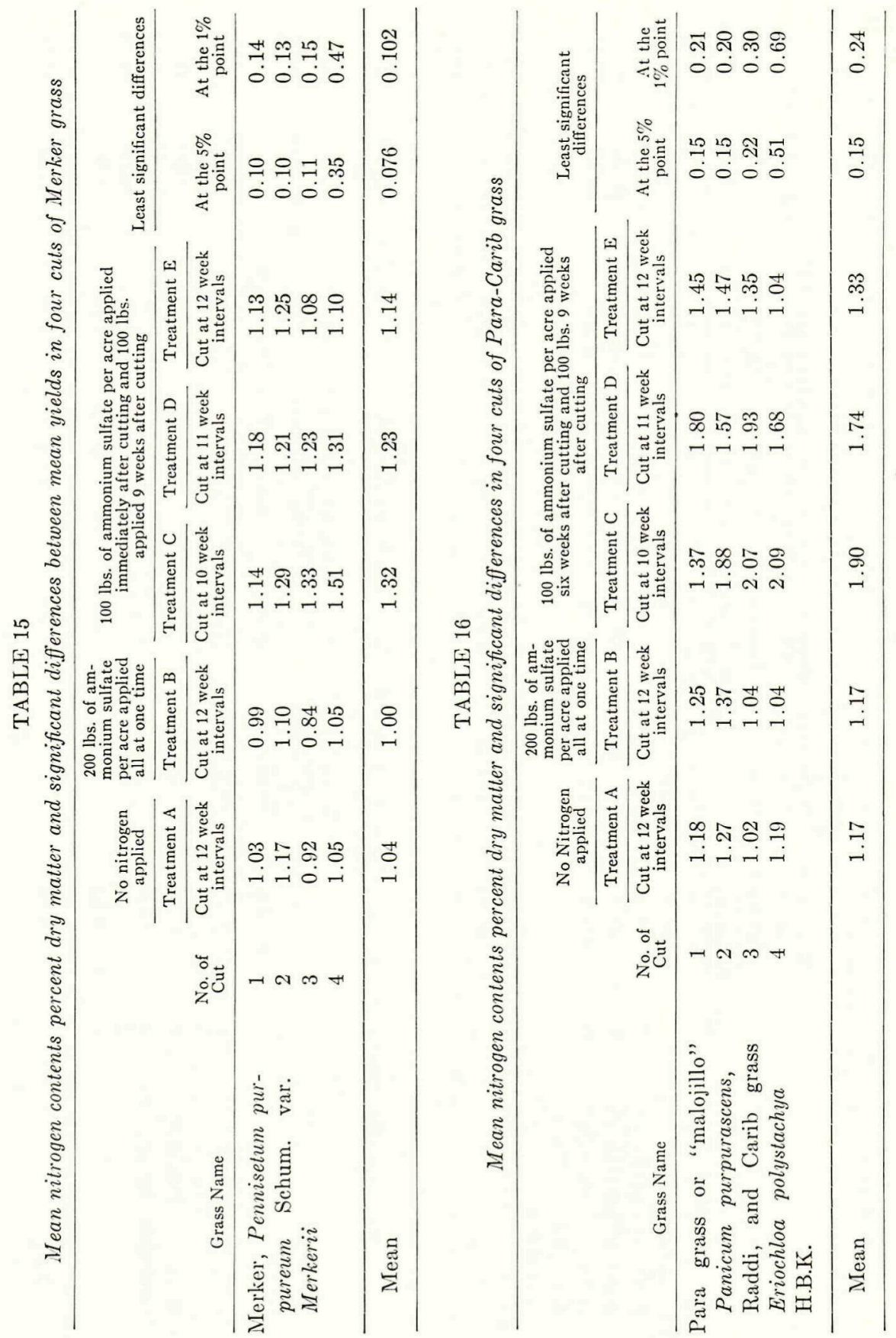


plied there is a more or less rapid assimilation of the nitrogen by the grass depending on the soil moisture, season of the year, and size of the plant, until a maximum content of nitrogen is attained. During this period the intake of nitrogen exceeds its utilization by the plant in forming new tissues. The maximum content probably occurs when these two processes are in equilibrium. Thereafter, the rate of utilization of nitrogen exceeds its rate of absorption, with a consequent reduction in per cent of dry matter. If enough time elapses, the nitrogen content per cent dry matter of the grasses fertilized with nitrogen may be reduced through growth to about the same level as that of the unfertilized grasses. This may be seen on comparing the nitrogen content of the grasses grown under treatment A (control) and treatment $B$, when all the nitrogen was applied at one time at the start of the growth cycle (tables 14, 15 and 16). As stated above, cutting the grasses at 12-weeks intervals gave higher yields of dry forage and protein per acre than cutting the grasses at 10-week intervals, in the case of Guinea and Merker grasses (tables 8, 9, 10 and 11). Maximum yields of dry forage and protein were obtained when the Para-Carib was cut at 11week intervals (tables 12 and 13). But as regard statistical differences, in the case of Guinea grass there were no significant differences between yields of dry forage and protein produced by grasses cut at 12 and 10 -week intervals (Tables 8 and 9). Merker grass had a significant difference at the $5 \%$ point (Tables 10 and 11). Para-Carib grass produced higher yields of dry forage and protein when cut at 11-week intervals, than at 12 and 10 -week intervals (Tables 12 and 13) but as regard the statistical differences were found that there were no significant differences between the protein produced, when cut at 12 and 10-week intervals, and protein produced when the grass was cut at 11-week intervals.

The age of the grasses has to do with their palatability, thus the cattle will eat it more readily when its palatability is improved. These facts lead to the conclusion that splitting the amount of nitrogen to be applied in two equal portions for two applications, and cutting the grass at 10 -week intervals will give us forage of superior quality, with a high protein content and of greatest palatability.

\section{CONCLUSIONS}

The yield of green forage and protein of our most important forage grasses is greatly increased by the application of nitrogen at the rate of fifty pounds of ammonia per acre.

When the nitrogen is applied all at one time and the grasses are cut at 12 -week intervals, the maximum yield of green forage was obtained when the Guinea grass received the fertilizer 3 weeks after planting, Merker 
grass immediately after planting, and the Para-Carib six wecks after planting.

When the nitrogen is applied all at one time and the grasses are cut at 12week intervals the maximum nitrogen content of the grasses was obtained when all the grasses received the nitrogen nine weeks after planting.

When the nitrogen was applied splitting the amount used and applying one-half the amount at the time each grass gave maximum yields of green forage, and one-half the amount nine weeks after cutting, maximum nitrogen content of the grasses was obtained when they were cut at 10-week intervals.

When the application of all the nitrogen at one time was compared to the application of nitrogen splitting the amount in two equal portions, the maximum yield of dry forage and protein occurred when the Guinea and Merker grasses were cut at 12-week intervals with all the fertilizer applied at once, and when the Para-Carib received one-half of the nitrogen six weeks after harvest and one-half nine weeks after cutting and the grass was harvested at 11-week intervals.

Good quality forage can be obtained by splitting the fertilizer to be applied into two equal portions for two applications and cutting the grass at 10 -week intervals. This forage will have both a high protein content and good palatability.

\section{SUMMARY}

This work gives useful information for the practical farmer. The production of green forage for feeding livestock, especially for dairy cattle, can be improved by the application of nitrogenous fertilizer at the proper time and in sufficient quantity to three important forage grasses. By the proper use of this information, green grasses high in protein can be made available in more ample quantities in the dairy farms of the Island than they are at present. That is, the dairy farmers could actually raise or maintain better pastures and a larger number of heads of cattle than are now raised on the land used for pasture.

Considering that Puerto Rico is very hard pressed for good agricultural lands, the possibility of increasing the production of animal products in the land now available for this purpose becomes of greatest importance.

In addition, with proper management of their pasture or silage grasses, dairy farmers can cut down on their expenses for concentrated feeds by increasing the protein content of their grasses.

\section{ACKNOWLEDGMENT}

The writer expresses his indebtedness to Dr. Bernardo G. Gapó, Assistant Director for Research, without whose constant encouragement and helpful 
criticism and advice this work could not have been undertaken. The writer also thanks Mrs. Socorro G. Urrutia of the Soils Department for carrying out the determinations of nitrogen and dry matter of the grass samples.

\section{LITERATURE CITED}

1. Alberts, H. W. and García Molinari, Ovidio. Pastures of Puerto Rico and their relation to soil conservation. U. S. Dept. Agr. Misc. Pub. 513 in cooperation Univ. of Puerto Rico, Agr. Exp. Sta. May 1943. Washington, D. C.

2. Brown, B. A. Effects of fertilizers on the seasonal production of pastures. Journal Am. Soc. Agron. 24: 898-908. (1932).

3. Brown, B. A. and Munsell, R. I., Grasses fertilized with nitrogen compared with legume for hay and pasture. Jour. Am. Soc. Agron. 35: 811-816, 1943.

4. Colós, E. D., Datos sobre la agricultura de Puerto Rico antes del 1898. San Juan, Puerto Rico, 1930.

5. Colwell, W. E., and Tisdale, Samuel L. A summary of the most recent works on nitrogen fertilization. Proc. Nat. H. Com. Fertilizer application, 25th. An. Mtg. 1949, page 52.

6. Dodn, D. R., The place of nitrogen fertilizers in a pasture fertilization programme. Jour. Am. Soc. Agron. 27: 853-862., 1935.

7. Hiтchсоск, A. S. Manual of the grasses of the West Indies. Misc. Publ. No. 243. U.S.D.A., Washington, D. C., 1936.

8. Hoover, Max M., Hein, M. A., Dayton William A., Erlanson, C. O., The main grasses for farm and home. Grass. The yearbook of Agri., 1948. U.S.D.A. Washington, D. C., 1948.

9. Macfarland, J., Time of application of nitrogen as a factor influencing the yield of herbage on permanent pastures. Emp. Jour. Exp. Agri., 7: 155-161, 1939.

10. Munseld, R. I., And Brown, B. A. The nitrogen content of grasses as influenced by kind, frequency of application and amount of nitrogenous fertilizer. Jour. Am. Soc. Agron. 31: 388-398, (1949).

11. Roberts, R. C. Soil survey of Puerto Rico. U.S.D.A. Bur. Plant Ind., in coop. Univ. of Puerto Rico, Agricultural Experiment Station, Series 1936, No. 8.

12. Woodman, H. E. and E. J. Underwood. Nutritive value of pastures. VIII. The influence of intensive fertilizing on the yield and composition of good permanent pastures (Seasons land 2). Jour. Agr. Sci. 22: 26-71, 1932.

13. Woodman, H. E., R. E. Evans and P. M. Oosthuizen, Nutritive value of pastures. XIV. The Influence on yield and composition of a single heavy dressing of sulphate of ammonia compared with that of periodic small dressing throughout the season. Jour. Agr. Sci. 28: 598-603. 1938. 